\title{
NAS TRILHAS DOS CLÁSSICOS
}

\author{
Mariângela Carvalho Cavalheiro *
}

\section{Introdução}

Há dezesseis anos ministro aulas em uma Escola da Rede Municipal de Sorocaba, sendo que quinze foram dedicados ao Ensino Médio.

A maior dificuldade que tive, no início de carreira, foi despertar o interesse dos alunos pela leitura de clássicos e, por conseguinte, envolvê-los nessa tarefa, isso não foi nada fácil, nem algo que pudesse acontecer de uma hora para outra.

Fora necessário um trabalho de base, de forma a seduzi-los pela curiosidade da história, ou seja, através de pequenos relatos de algumas passagens emocionantes, fui deixando sempre um gostinho de quero mais, dessa forma, consegui atraí-los e a sensação que restou foi a de que iriam gostar da leitura recomendada e referenciada.

\section{A leitura dos Clássicos}

A seleção da obra clássica é de suma importância, pois a todo o momento os estudantes solicitam leituras que estão na mídia e, que muitas vezes não trazem bons exemplos a serem seguidos. Por outro lado, se escolhermos um livro enfadonho, estaremos apostando na perda e não na conquista de leitores.

A partir do momento em que os educandos se tornam leitores de clássicos, verifica-se que há mudança de comportamento, isso porque estão em contato com exemplos estéticos e éticos, elementos importantes para a formação de um ser humano que se preocupa com seu próximo e, o respeite acima de tudo.

Dentre as mais variadas formas que trabalhei com clássicos em sala de aula (resenha, dramatização, análise escrita e interpretativa, roda de conto, etc.) a que mais rendeu resultados positivos foi o debate.

\section{O debate sobre a obra}

Professora Efetiva da Rede Municipal de Sorocaba/SP, Escola Municipal Prof. Flávio de Souza Nogueira.Graduação em Letras. Pós- Graduação direcionada ao ensino e à pesquisa em Literatura Brasileira e Portuguesa. Autora de “A Produção Literária de Júlio Ribeiro em Sorocaba”, editora Linc, 2001. 
Através do debate de obras clássicas, os estudantes se envolvem, apresentam argumentos coerentes, acionados pelos mecanismos de memória e conhecimento de mundo, desenvolvendo, mormente o respeito ao turno de fala e a escuta atenta, havendo a necessidade, é óbvio, o posicionamento do professor como mediador das réplicas.

Já há alguns anos tenho executado esse tipo de atividade, a qual é apreciada pela maioria dos estudantes.

Para este ano, selecionei duas obras que foram distribuídas para leitura paradidática entre três segundos anos do Ensino Médio noturno.

Uma delas foi o "Santo Inquérito" - de Dias Gomes e a outra uma adaptação do clássico "Dom Quixote", de Miguel de Cervantes editado pela Scipione.

Como estávamos estudando o estilo Barroco, esses dois exemplos de leitura muito auxiliaram na compreensão da Escola Literária, igualmente, no conhecimento de História que fora desenvolvido paralelamente.

A primeira obra, em linhas gerais, trata-se da personagem Branca Dias- uma cristã nova que salva a vida de Padre Bernardo e o reanima através de respiração boca a boca. Esse ato faz com que o Padre se apaixone pela moça e a entregue ao Santo Ofício para ser julgada.

A segunda obra versa sobre Dom Quixote, um ávido leitor de clássicos que acabou acreditando que ainda estava na época da cavalaria medieval, assim, comete grandes loucuras em nome da justiça e da liberdade.

Cada sala fora dividida entre números pares e ímpares- sendo os pares responsáveis por defender Branca Dias e os ímpares defender o ponto de vista de Padre Bernardo.

Os argumentos apresentados foram muitos, salientando apenas alguns extraídos pela recorrência à memória: "Jesus ensinou que devíamos amar ao nosso próximo como a nós mesmos e Branca Dias fez exatamente isso, preservou a vida de seu semelhante"; em contrapartida: "Padre Bernardo não pediu isso a ela, ele já entregara sua alma a Deus quando o barco naufragou, além do que era ele o representante de Deus na Terra, através da Igreja a qual estava vinculado".

No caso de "Dom Quixote", também divididos em pares e impares os alunos defenderam D. Quixote, no caso os ímpares e o acusaram de insanidade, os pares.

"A defesa de Dom Quixote: "Ele não era louco, só possuía uma grande imaginação, além do que era justo para com todos e, dizer que uma pessoa é louca só porque coloca apelidos nas pessoas, é dizer que toda humanidade é louca também"; a antítese utilizada:" Se ele não era louco porque quando colocou a bacia repleta de requeijão na cabeça começou a se queixar de que seu cérebro estava derretendo?".

$\mathrm{E}$ assim, procedemos como se estivéssemos em um Tribunal, havendo momentos em que os alunos se envolviam tanto que parecia mesmo um caso real, de justiça até.

Ao propor essa atividade, meus objetivos eram fazer com que os alunos lessem obras clássicas, tivessem contato com bons exemplos e aprendessem a argumentar com conhecimento de causa, utilizando-se de situações plausíveis, que mantivessem seu ponto de vista, mesmo que a princípio discordassem do personagem defendido por eles e, acima de tudo, que melhorassem esse posicionamento crítico através de um artigo de opinião. 
Primeiramente, essa atividade gerou uma participação de $90 \%$ de cada classe, o objetivo primeiro fora alcançado- motivar os alunos à leitura de clássicos.

Sempre que peço uma nova leitura, eles vão à procura da obra na biblioteca da Escola. são solicitadas oito obras por ano, distribuídas duas por bimestre.

A atividade gerou um gostinho de quero mais, entretanto, ela é realizada a todo o momento, porque há necessidade de se trabalhar a oralidade, mas também a escrita é muito importante.

E, por último, observei uma melhora significativa nas avaliações de artigos de opinião, tendo como parâmetro antes e após o debate.

É importante salientar que nenhuma atividade proposta surtirá efeito positivo se não houver o apoio dos colegas professores, da coordenação da Escola e da Direção, todos trabalhando em parceria.

Particularmente, fiquei muito feliz com o desempenho dos estudantes, que a cada novo debate vibram, argumentam, inferem e concluem situações; esse foi o caminho encontrado por mim.

Abstract: In this diary I present the possibility of reading literature classics in class, at high school level. The results were very significant, being this kind of reading often repudiated by students.

Keywords: teaching, reading, literature classics 